\title{
Thalassorama
}

\section{Hawaii Longline Vessel Economics}

\author{
MARCIA S. HAMILTON \\ RITA E. CURTIS \\ MICHAEL D. TRAVIS \\ University of Hawaii
}

\section{Introduction}

This note describes the results of a multi-year economics research project at the University of Hawaii's Joint Institute for Marine and Atmospheric Research (JIMAR) designed to provide baseline economic information on the Hawaii-based longline fishery. Longline fishing involves the use of a mainline [2-100 kilometers $(\mathrm{km})$ in length], which is strung across the ocean's surface using floats to which branch lines with baited hooks are attached at intervals. Fishing depth is adjusted depending on the species targeted (tunas, swordfish, and other pelagic fishes).

Longline fishing by Hawaii-based vessels began in 1917 (Boggs and Ito 1993), but was severely reduced during World War II and remained low until the mid 1980s (fifteen vessels). By 1990 the fleet expanded to over 150 vessels due in part to increased export demand for Hawaiian fish (Pooley 1993). Beginning in 1991, fishery managers imposed a limited entry regime. In 1993 longline fishing permits were issued for 167 longline vessels, 122 of which made at least one landing. This study focuses on the fleet operating in 1993.

Total 1993 fleet landings, as estimated by National Marine Fisheries Service, were 25 million pounds, with an ex-vessel value of $\$ 55$ million. Hawaii-based longline vessels fished in an area between $125 \mathrm{~km}$ and $3,500 \mathrm{~km}$ from Honolulu, with fishing effort roughly split between the inside and the outside of Hawaii's 200 mile Exclusive Economic Zone (EEZ) (Dollar 1994). The major species targeted were swordfish (52\% of landings by weight), and tunas ( $29 \%$ of landings). Miscellaneous other pelagic species include marlin, mahimahi, and wahoo and comprised $19 \%$ of landings. This report provides a summary of 1993 vessel operations and earnings; information on other years will be available in the near future.

\section{Methodology}

Personal interviews were conducted during the summer of 1994 with the owners and/or captains of ninety-five of the 122 active Hawaii-based longline vessels. A survey of approximately seventy-five questions was administered, primarily focusing on vessel characteristics and costs. Catch, revenue, and operating information

Marcia S. Hamilton is research associate; Rita E. Curtis is research associate; and Michael D. Travis is assistant researcher at the Joint Institute for Marine and Atmospheric Research, University of Hawaii, Honolulu, Hawaii 96822 USA. Hamilton's e-mail: mhamilto@honlab.nmfs.hawaii.edu 
was extracted on a per vessel basis from a combination of State of Hawaii catch reports and federal logbooks.

Based on interview data, the fishery was categorized into four categories ${ }^{1}$ according to vessel target: (1) TUNA indicates every trip (and set) targeted tunas, (2) MIXED indicates every trip (and set) was "catch whatever you can," (3) SWORD indicates every trip (and set) targeted swordfish, and (4) VARIED indicates target varied by trip.

\section{Results and Discussion}

\section{Analysis by Target Species}

Of the 122 vessels active in 1993, one-third targeted tuna, one-third had a mixed target strategy and $20 \%$ targeted swordfish (table 1). Tuna and swordfish longliners represented two ends of a spectrum in terms of vessel horsepower, gross tons, total investment (purchase price plus additional investment), number of trips, travel days, fishing days, and catch per trip. Mixed and varied target vessels fell in the middle, with mixed vessels tending to be larger, but with lower levels of investment.

In terms of annual revenue and variable costs, tuna and swordfish vessels were again at the two extremes (table 2). Variable costs were higher for swordfish boats, because in addition to traveling farther to their fishing grounds (higher fuel costs) and making more sets (higher quantities of bait), they also used a more expensive type of bait and utilized a larger number of lightsticks to attract the fish to the bait. Mixed boats had the lowest fixed costs, and swordfish boats had the highest. Several of the factors that contribute to high fixed costs are related to vessel value including loan payments, insurance costs, and depreciation charges. The mean value (purchase price plus additional investment) for mixed vessels was $40 \%$ less than that of swordfish vessels. Mean annual net returns were highest for mixed boats and lowest for varied target boats.

A comparison of means to medians for net returns revealed that the distribution

Table 1

Mean Vessel and Operating Characteristics by Target

\begin{tabular}{lcccc}
\hline & \multicolumn{4}{c}{ Vessel Target } \\
\cline { 2 - 5 } & Tuna & Mixed & Sword & Varied \\
\hline $\mathrm{N}$ & 41 & 41 & 26 & 3 \\
Vessel length (feet) & 60 & 75 & 72 & 64 \\
Gross tons & 65 & 109 & 118 & 91 \\
Total horsepower & 342 & 519 & 566 & 362 \\
Purchase price & $\$ 172$ & $\$ 236$ & $\$ 446$ & $\$ 277$ \\
Additional investment $^{\mathrm{a}}$ & $\$ 133$ & $\$ 84$ & $\$ 94$ & $\$ 110$ \\
Value of electronics $^{\mathrm{a}}$ & $\$ 22$ & $\$ 23$ & $\$ 79$ & $\$ 19$ \\
Number of trips in 1993 & 12.6 & 10.8 & 7.7 & 11.9 \\
Total days per trip & 13.8 & 18.8 & 32.2 & 19.6 \\
Travel days per trip & 4.6 & 9.0 & 18.2 & 8.9 \\
Fishing days per trip & 9.2 & 9.8 & 14.0 & 10.8 \\
Catch per trip (pounds) & 12,187 & 18,811 & 26,132 & 12,373 \\
\hline
\end{tabular}

${ }^{a}$ In thousands of dollars.

${ }^{1}$ Two vessels which varied their target species by set are omitted from the analysis. 
of net returns was skewed slightly negatively for both tuna and swordfish vessels, and skewed positively for mixed and varied vessels. Of the thirty-two tuna vessels surveyed, nineteen had positive annual net returns in 1993; the remaining thirteen showed negative returns. Within swordfish vessels, eleven had positive net returns while ten realized net losses. For mixed vessels, twenty-eight had positive annual net returns and four had negative returns.

\section{Analysis of Economic Highliners}

For the purposes of this study, economic highliners were defined as the three vessels which earned the highest annual net return within a given group. Economic highliners had higher levels of total investment, larger vessels and more electronics than did other vessels (table 3 ). They also took more and longer trips, caught more pounds per trip and secured higher output prices.

Although the annual variable costs of highliners were higher than those of other

Table 2

Mean Annual Economic Information per Vessel $(\$ 1,000)$

\begin{tabular}{lcccr}
\hline & \multicolumn{4}{c}{ Vessel Target } \\
\cline { 2 - 4 } & Tuna & Mixed & Sword & Varied \\
\hline Gross revenue & 355 & 566 & 633 & 491 \\
Variable costs & & & & 132 \\
$\quad$ Labor & 113 & 135 & 139 & 179 \\
$\quad$ Supplies & 96 & 237 & 252 & 51 \\
$\quad$ Sales fees & 35 & 57 & 101 & 2 \\
$\quad$ Excise taxes & 2 & 3 & 3 & 28 \\
Fixed costs & 24 & 16 & 35 & 27 \\
$\quad$ Insurance & 22 & 28 & 26 & 38 \\
$\quad$ Maintenance & 10 & 11 & 18 & 5 \\
$\quad$ Depreciation & 34 & 32 & 48 & 11 \\
$\quad$ Other & 20 & 47 & & \\
Net return & & & &
\end{tabular}

Table 3

Comparison of Fleet Highliners to all Other Vessels: Mean Vessel and Operating Characteristics.

\begin{tabular}{lcc}
\hline & Highliners & All Other Vessels \\
\hline Vessel length (feet) & 73 & 68 \\
Purchase price $^{\mathrm{a}}$ & $\$ 350$ & $\$ 264$ \\
Additional investment $^{\mathrm{a}}$ & $\$ 47$ & $\$ 108$ \\
Value of electronics $^{\mathrm{a}}$ & $\$ 46$ & $\$ 34$ \\
Number of trips $_{\text {Total days per trip }}$ & 12.3 & 10.7 \\
Catch per trip (pounds) $_{\text {Price per pound }}$ & 22.1 & 20.1 \\
Gross revenue per trip & 27,276 & 17,699 \\
& $\$ 3.04$ & $\$ 2.81$ \\
\hline
\end{tabular}

a In thousands of dollars. 
Table 4

Comparison of Fleet Highliners to all Other Vessels: Average Annual Economic Information per Vessel $(\$ 1,000)$

\begin{tabular}{lrc}
\hline & Highliners & All Other Vessels \\
\hline Annual gross revenue & 967 & 489 \\
Labor & 297 & 123 \\
Supplies & 259 & 185 \\
Sales fees & 85 & 58 \\
Excise taxes & 5 & 2 \\
Total variable costs & 646 & 368 \\
Insurance & 18 & 24 \\
Maintenance & 14 & 26 \\
Depreciation & 13 & 12 \\
Drydock & 14 & 9 \\
Other & 29 & 29 \\
Total fixed costs & 88 & 100 \\
Annual net return & 233 & 21 \\
\hline
\end{tabular}

vessels, they were offset by lower fixed costs, higher annual catches, higher output prices, and higher annual gross revenues (table 4).

\section{Conclusion}

This study found that, while the Hawaii longline fleet averaged a positive net return from their 1993 operations, the level of profits varied substantially between groups of vessels. When analyzed by target species, mixed target vessels earned the highest net return. Although the gross revenue earned by this group was less than that earned by swordfish vessels, mixed vessels had somewhat lower variable costs and substantially lower fixed costs.

The lowest net returns were earned by varied and swordfish vessels. Varied vessels ranked third in gross revenues as well as variable costs, but encountered high fixed costs. Swordfish vessels realized the highest gross revenue; however, they also had the highest variable and fixed costs of all groups. These findings imply that the role of fixed costs in the ranking of net returns by sector may be more important than that of either gross revenue or variable costs.

An examination of economic highliners revealed that these vessels tended to achieve greater gross revenues through higher sales levels, higher output prices and lower costs. It is this combination of higher revenues and lower costs which distinguished economic highliners within every group examined. Additional analyses of economic dynamics of the Hawaii based longline fishery are ongoing.

\section{References}

Boggs, C. F. and R. Y. Ito. 1993. Hawaii's Pelagic Fisheries. Marine Fisheries Review 55(2):69-82.

Dollar, R. A. 1994. Annual Report of the 1993 Western Pacific Longline Fishery. U.S. Department of Commerce, NOAA, National Marine Fisheries Service, Southwest Fisheries Science Center. Administrative Report H-94-06.

Pooley, S. G. 1993. Hawaii's Marine Fisheries: Some History, Long-term Trends, and Recent Developments. Marine Fisheries Review 55(2):7-19. 